\section{Distribution of Nuclease O Inhibitor among Aspergillus Species}

\author{
Takeshi Uozumi and Kei ARIMA \\ Department of Agricultural Chemistry, \\ The University of Tokyo, Tokyo \\ Received March 4, 1974
}

There are many reports on deoxyribonuclease and ribonuclease inhibitors of protein nature, such as DNase inhibitors of mammalian tissues ${ }^{1,21}$ and $A C$ tinomyces levoris ${ }^{31}$ and RNase inhibitors of mammalian tissues, ${ }^{4,5)}$ Bacillus subtilis ${ }^{6}$ and Aspergillus clavatus. ${ }^{7 !}$ Generally, such inhibitors are highly specific to the particular enzymes of the same strains. As for nucleases which degrade both DNA and RNA, only two instances of such inhibitors have been reported to our knowledge. The one is the nuclease $O$ inhibitor of Aspergillus oryzae, ${ }^{8,91}$ and the other is that of Neurospora crassa. ${ }^{10}$ The nuclease $\mathrm{O}$ inhibitor of $A$. oryzae, found in the fresh mycelia of the organism, is a heat stable protein with a molecular weight about 23,000 . The inhibitor is specific to nuclease $\mathrm{O}$ (EC 3.1.4.9), ${ }^{11 /}$ an intracellular nuclease of $A$. oryzae, and does not affect nuclease $\mathrm{S}_{1}$, ribonuclease $\mathrm{T}_{1}$ and ribonuclease $\mathrm{T}_{2}$ of $A$. oryzae and pancreatic RNase. The inhibitor stoichiometrically inactivates nuclease $O$ forming a stable complex with the nuclease. The inhibitor in the mycelia is inactivated in the course of autolysis of the organism, resulting in 3-fold activation of intracellular nuclease activity, which is accompanied by decomposition of more than $90 \%$ of cellular nucleic acids. This time, we investigated the distribution of the inhibitor of nuclease $O$ among Aspergillus species, and found that the inhibitor is present in all strains of $A$. oryzae tested and some species closely related to $A$. oryzae.

Crystalline nuclease $\mathrm{O}^{12}$ prepared from the autolyzate of $A$. oryzae IAM 2608 was used for determination of the inhibitor activity by the assay method previously reported.97 One loopful of spores of test organism from a slant culture was inoculated into $100 \mathrm{ml}$ medium (sucrose $3.5 \%$, polypeptone $2 \%, \mathrm{KH}_{2} \mathrm{PO}_{4} \quad 0.5 \%$, $\mathrm{MgSO}_{4} \cdot 7 \mathrm{H}_{2} \mathrm{O} 0.25 \%$, pH 5.6) in $500 \mathrm{ml}$ Sakaguchi flask, and incubated at $30^{\circ} \mathrm{C}$ for $41 \mathrm{hr}$ with reciprocal shaking at 120 strokes per minute. The mycelia were harvested by filtration through a Buchner funnel, washed twice with distilled water, and blotted by pressing them between sheets of filter paper. Two grams of mycelia were mixed with $4 \mathrm{~g}$ of glass powder and $20 \mathrm{ml}$ of $0.05 \mathrm{M}$ Tris- $\mathrm{HCl}$ buffer ( $\mathrm{pH} 7.2$ ), and homogenized in an ice-cold Waring blender for $5 \mathrm{~min}$. The homogenate was heated at $80^{\circ} \mathrm{C}$ for $10 \mathrm{~min}$ to denature nucleases and other proteins, and centrifuged at $500 \times g$ for $10 \mathrm{~min}$. The inhibitor activity against nuclease $O$ in the supernatant was determined using yeast RNA and heat-denatured herring sperm DNA as substrates.

TABle I. Distribution OF the INHIBITOR of Nuclease O among Aspergillus Species

\begin{tabular}{|c|c|c|}
\hline Strain & $\begin{array}{l}\text { Inh } \\
\text { (U/g wet } \\
\text { RNA as } \\
\text { substrate }\end{array}$ & $\begin{array}{l}\text { bitor } \\
\text { mycelia) } \\
\text { DNA as } \\
\text { substrate }\end{array}$ \\
\hline A. oryzae IAM 2608 & 1.3 & 1.3 \\
\hline A. oryzae IAM 2604 & 1.3 & 1.3 \\
\hline A. oryzae IAM 2609 & 1.4 & 1.3 \\
\hline A. oryzae IAM 2742 & 1.1 & 1.1 \\
\hline A. oryzae IAM 2734 & 1.2 & 1.2 \\
\hline A. oryzae IAM 2630 & 1.2 & 1.1 \\
\hline A. oryzae IAM 2142 & 1.3 & 1.2 \\
\hline $\begin{array}{l}\text { A. oryzae var. } \\
\text { globosus IAM } 2645\end{array}$ & 1.1 & 1.1 \\
\hline $\begin{array}{l}\text { A. oryzae var. } \\
\text { microsporus IAM } 2728\end{array}$ & 1.1 & 1.1 \\
\hline $\begin{array}{l}\text { A. oryzae var. } \\
\text { magnasporus IAM } 2719\end{array}$ & 0.4 & 0.6 \\
\hline A. flavus IAM 2007 & 1.3 & 1.2 \\
\hline A. flavus IAM 2184 & 1.5 & 1.4 \\
\hline A. sojae IAM 2678 & 0.7 & 0.7 \\
\hline A. sojae IAM 2634 & 0.9 & 0.8 \\
\hline A. parasiticus IAM 2150 & 0.4 & 0.5 \\
\hline A. parasiticus ATCC 15517 & 0.3 & 0.4 \\
\hline A. tamarii IAM 2138 & 0.4 & 0.6 \\
\hline A. tamarii IAM 2178 & 0.4 & 0.6 \\
\hline A. saitoi IAM 2215 & 0.2 & 0.2 \\
\hline A. saitoi var. & & \\
\hline kagoshimaensis IAM 2192 & 0.0 & 0.0 \\
\hline A. niger IAM 2107 & 0.0 & 0.0 \\
\hline A. niger IAM 3008 & 0.0 & 0.0 \\
\hline A. awamori IAM 2312 & 0.3 & 0.2 \\
\hline A. awamori var. & & \\
\hline fumeus IAM 2388 & 0.0 & 0.0 \\
\hline A. clavatus IAM 2120 & 0.6 & 1.2 \\
\hline A. fumigatus IAM 2129 & 0.4 & 0.5 \\
\hline A. nidulans IAM 2155 & 0.4 & 0.5 \\
\hline A. japonicus IAM 2083 & 0.5 & 0.5 \\
\hline A. flavipes IAM 2160 & 0.2 & 0.4 \\
\hline A. ochraceus IAM 2804 & 0.1 & 0.2 \\
\hline A. ustus IAM 2057 & 0.1 & 0.2 \\
\hline A. versicolor IAM 2080 & 0.0 & 0.3 \\
\hline A. terreus IAM 2179 & 0.0 & 0.1 \\
\hline A. candidus IAM 2015 & 0.0 & 0.1 \\
\hline A. inuii IAM 2255 & 0.0 & 0.0 \\
\hline A. wentii IAM 2133 & 0.0 & 0.0 \\
\hline A. glaucus B (A-1-6) & 0.0 & 0.0 \\
\hline
\end{tabular}

As shown in Table I, nearly the same level (1.1 $1.4 \mathrm{U} / \mathrm{g}$ mycelia) of inhibitor was found in all the seven strains of $A$. oryzae randomly sampled from the culture 
collections of our laboratory. Three strains of $A$. oryzae variety and two strains from each of $A$. flavus, $A$. sojae, $A$. parasiticus and $A$. tamarii, which are taxonomically closely related to $A$, oryzae, also contained the inhibitor. Therefore, it may be concluded that the nuclease $\mathbf{O}$ inhibitor is present in all species closely related to $A$. oryzae. On the other hand, little or no inhibitor activity against nuclease $O$ was detected in black aspergilli and some other species of Aspergilli, although the present data do not exclude the possibility that these aspergilli may also have their own nucleaseinhibitor system. The presence or absence of such nuclease-inhibitor system and cross reaction of nuclease and inhibitor among different species of Aspergilli may be an interesting problem for taxonomy of Aspergilli.

Acknowledgement. The authors are grateful to Associate Professor Teruhiko Beppu for his useful discussion about this work.

\section{REFERENCES}

1) U. Lindberg, Biochemistry, 6, 343 (1967).
2) G. Berger et P. May, Biochim. Biophys. Acta, 139, 148 (1967).

3) A. A. Baskakova, A. V. Baldina and A. M. Bezborodov, Mikrobiologiya, 41, 77 (1972).

4) J. S. Roth, Biochim. Biophys. Acta, 61, 903 (1962).

5) A. A. M. Gribnau, J. G. G. Schoenmakers and H. Bloemendal, Arch. Biochem. Biophys., 130, 48 (1969).

6) J. R. Smeaton and W. H. Elliott, Biochim. Biophys. Acta, 145, 547 (1967).

7) G. S. Ivanova and A. M. Bezborodov, Mikrobiologiya, 41, 224 (1972).

8) T. Uozumi, G. Tamura and K. Arima, Agr. Biol. Chem., 32, 969 (1968).

9) T. Uozumi, G. Tamura and K. Arima, ibid., 33, 636 (1969).

10) K. Hasunuma and T. Ishikawa, Genetics, 70, 371 (1972).

11) T. Uozumi, T. Hino, G. Tamura and K. Arima, Agr. Biol. Chem., 36, 434 (1972).

12) T. Uozumi, G. Tamura and K. Arima, ibid., 33, 645 (1969). 